\author{
Melissa Shih-hui Lin \\ National Chengchi University, Taiwan
}

\title{
LIMITS OF THE EU LANGUAGE EDUCATION POLICY FOR MIGRANTS: A COMPARATIVE STUDY OF THE VIETNAMESE MIGRANT COMMUNITY IN THE CZECH REPUBLIC AND THE NEW IMMIGRANTS IN TAIWAN
}

Summary. The aim of Council of Europe language education policies is to promote plurilingualism, linguistic diversity, mutual understanding, democratic citizenship and social cohesion. For migrant communities, the current approaches for linguistic integration are Linguistic Integration of Adult Migrants (LIAM) and Linguistic and Educational integration of children holding a migrant background. Nevertheless, due to the current refugee crisis in Europe, the realization of these strategies is quite limited and facing unexpected difficulties, which both are the core issues discussed in this paper. The Vietnamese arrived in Czech Republic in 1970s and 1980s as guest-workers. According to the 1985 census data from CZSO (Czech Statistical Office), there were 19,350 Vietnamese living in the Czech territory, but by 1994 the number decreased to approximately 8,000. Then, according to the census in 2014, due to the changes in both political and economic environment, the number of the Vietnamese in the Czech Republic increased from 18,210 to 52,612, spanning from 2001 to 2011. Nevertheless, this figure seems to greatly underestimate the real number of the Vietnamese living in the Czech Republic, mainly due to numerous undocumented immigrants of illegal migration. According to CZSO, the Vietnamese community constituted $12.5 \%$ of migrant population in the territory of the Czech Republic in 2014, serving as the third largest migrant community after Slovak and Ukraine communities. The Czech government conducts language policy programs for migrant integration, while the development has brought both positive and negative impact to the whole society, which will be further discussed in this paper and expanded into as an empirical study of the situation in the European context. The conclusion of this paper will enlist the problems and influence of Taiwan's current new immigrant language education policy, serving as a reference for the current refugee crisis, along with specific focus on its linguistic integration in Europe.

Keywords: Migration, linguistic integration, linguistic right, Vietnamese in Czech, European Union, Taiwan new immigrants.

\section{Introduction}

Migration is defined by UNESCO ${ }^{20}$ as "the crossing of the boundary of a political or administrative unit for a certain minimum period of time. It includes the movement of refugees, displaced persons, uprooted people as well as economic migrants." The main goal of migration often links to job-hunting, better qualities of life, reunion with family members, or to escape persecution or environment

${ }^{20}$ See: www.unesco.org. 
LIMITS OF THE EU LANGUAGE EDUCATION POLICY FOR MIGRANTS: A COMPARATIVE STUDY OF THE VIETNAMESE MIGRANT COMMUNITY IN THE CZECH REPUBLIC AND THE NEW IMMIGRANTS IN TAIWAN

disaster (Jackson \& Pasarelli, 2008) Generally speaking, migration is believed to benefit both the migrants themselves and the countries receiving them ${ }^{21}$. Primarily, the variety in aspects brought by the move of migration shall benefit the society as a whole, despite of the fact that this perspective is not necessarily supported by public (Council of Europe, 2008a). The Eurostat survey result of the relationship between a migrant and the host country in 2007 showed that $54 \%$ of respondents said that "immigrants enriched the cultural life of their country" (European Commission, 2007, p. 69) and $46 \%$ of respondents considered immigrants competing for jobs with the indigenous population increased unemployment in their country. Furthermore, 50\% of Europeans believed their country has too many immigrants.

Constant migration flows may possibly complicate the situation. One of the important issues among the rapid changes in flows is the case for granting linguistic rights, which theoretically aims to pursue either fairness or variety in linguistics, or both. Within a growing number of publications on immigrant communities, a few focuses on linguistic rights (Marta, 1991; Steiner-Khamsi, 1989) and less of which consider autochthonous and immigrant language rights simultaneously, except in such settings, where the distinction between "immigrant" and "autochthonous" is not as sharp as in Europe (Marshall, 1986). According to Grin (1995), in recent papers, both types of rights are considered, but the focus is alternately put on immigrant and autochthonous language rights (Guy, 1989; Skutnabb-Kangas \& Phillipson, 1989).

As Grin (1995) pointed out:

Present-day migrants are more likely, on average, to claim a right to maintain the language and culture of their native country in their new surroundings. This gives rise to a new category of minorities, who ground their legitimacy not in a historical connection with the piece of land on which they happen to live, but in a non-territorial right to the maintenance of cultural and linguistic identity (p. 33).

He further presented two well-known principles to implement linguistic rights by the authority of language plans and policies, which are the territorial principle and

${ }^{21}$ Report presented by the Secretary General of the United Nations, 6 June 2006. 
the personality principle. The former is tied to land. Every language should hold the highest density of use in a geographic area, which can be relatively homogeneous. Individuals then derive their linguistic rights from their communities' geographical location. Switzerland is a typical example, where there are four official autochthonous languages in designated regions: Schwyzertutsch, French, Italian and Romansch. The personality principle means that linguistic rights are granted to individuals, regardless of their location. In this case, Canada could serve as an example for French speakers can claim their linguistic rights anywhere in the country. Although there are obvious contrasts between these two principles, Grin (1995) argues they can be seen as complementary, which is also supported in this paper. He claims that the countries conducting the personality principle could switch to the territorial principle, and vice versa. His argument ultimately realizes the multilingualism.

However, it is not easy to pursue multilingualism as an ideal. The International Organization for Migration places "integration" in the middle of a continuum spanning assimilation to multiculturalism, stating that assimilation expects migrants to "adjust entirely to the values and the rights system of the host society". ${ }^{22}$ And integration is "the process of inclusion of immigrants in the institutions and relationships of the host society" (Boswick \& Heckman, 2006, p. 1). To achieve multilingualism, there must go the process of integration, which is exactly the main approach of EU to take on facing the current refugee's migration crisis. At present, the migration of from Syria and other conflict zones is a humanitarian catastrophe across the countries in the Middle East, Europe, and so on. In the European Union, the numbers of asylum seekers is getting higher. The figures published by "World Migration in Figures" of OECD in October $2013^{23}$ on the number of international migrants in Europe along the timeline are: 49 million in 1990, 56.2 million in 2000, 69.2 million in 2010 and 72.4 million in 2013. In 2015, asylum applications have surpassed any of those in the last thirty years. This phenomenon raises questions about the EU's ability to integrate the newcomers into the society (Aiyar et al., 2016).

In this paper, firstly, EU approaches for linguistic integration will be briefly introduced; secondly, the strategy and current situation of the third major

22 See: http://www.iom.int/.

23 See: http://www.oecd.org/els/mig/World-Migration-in-Figures.pdf. 
LIMITS OF THE EU LANGUAGE EDUCATION POLICY FOR MIGRANTS: A COMPARATIVE STUDY OF THE VIETNAMESE MIGRANT COMMUNITY IN THE CZECH REPUBLIC AND THE NEW IMMIGRANTS IN TAIWAN

migration community in the Czech Republic, the Vietnamese, will be targeted asan empirical study in this paper. It follows with the discussion of some limits of EU linguistic integration approaches threatened by flows of refugees' migration. Finally, some problems and influences of Taiwan's current new immigrant language policy will be discussed for reference.

\section{EU linguistic integration approaches for migrants}

\section{Background and development}

In 1977, there was the first directive related to the language education of children from a migrant background: Council Directive 77/486/EEC (Hoffmann, 1991); however, it was more of a formal method, not particularly being put in practice. In 2005, right after the EU enlargement in 2004, the 3rd Summit of Heads of States and Government of the Council of Europe's 46 member states took place in Warsaw. The Summit Declaration was committed to ensuring that the cultural diversity becomes a source of mutual enrichment and to protecting the rights of national minorities and the free movement of persons:

In order to develop understanding and trust among Europeans, we will promote human contacts and exchange good practices regarding free movement of persons on the continent, with the aim of building a Europe without dividing lines... (Council of Europe, 2008a, p. 5)

This political Declaration is accompanied by an Action Plan, which proposes measures to ensure social cohesion and addresses the management of migration, including the acquisition of visa, residence and citizenship. Presently, constant global migrations have brought EU to face the growing difficulties to integrate the newcomers. The linguistic integration of adult migrants has accordingly been appointed to be the subject of two intergovernmental conferences, held in June, 2008 and June, 2010, under the auspices of the Steering Committee for Education (CDED) and the European Committee on Migration (CDMG). The 2008 conference focused more on Council of Europe principles; the 2010 conference provided a forum, in which representatives of member states could discuss 
language requirements linked to entry, residence and citizenship, and the quality of language courses, language tests and alternative approaches to assessment. ${ }^{24}$ These two conferences formally confirmed the emphasis on the host language requirement in linguistic integration for migrants. In other words, the host language requirement is becoming a significant element of migration and integration approaches in most of EU member states (Council of Europe, 2014). Consequently, there is a steady increase in the number of countries enacting legislation to make language proficiency a requirement for residence, citizenship and even entry-visa. In the following, some data from the three Council of Europe surveys ${ }^{25}$ will be shown to present this tendency. However, if we trace back to the original motivation of linguistic integration policy, which is "in order to develop understanding and trust among Europeans", quoted from the mentioned above, and take into account that the recent Hungarian migrant quota referendum in this October, there are some phenomenon worthy of being discussed. This referendum was related to the European Union's migrant relocation plans mainly for the current refugee crisis. Although the low turnout rate rendered the referendum invalid at the end, the whole process reveals the collapse of the socalled European Values in this territory. The racism and xenophobia in Hungary seem to reach its peak during the whole process, and it recalls the importance to consider whether the tendency of current linguistic integration policy, i.e. the host language requirement as a significant element of migration and integration approaches in EU, is adequate to face the current complicated issues of migrants in Europe. If it is insufficient, what the policymakers should do is to regard such policy more comprehensively: the linguistic integration policy should emphasize not only the host language education, but also the education of migrants' mother tongues and their cultures, in order to promote the mutual understanding between the host society and the migrants.

\footnotetext{
24 See: www.coe.int/lang-migrants.

25 In 2002 and 2007, there were two surveys carried out by the Association of Language Testers in Europe (ALTE: www.alte.org). A second round survey was carried out by the Council of Europe at the end of 2009 and the findings were presented at the 2010 conference. In preparation for the 2014 conference a third survey was conducted among Council of Europe member states between April and July 2013, to which 36 states responded.
} 
LIMITS OF THE EU LANGUAGE EDUCATION POLICY FOR MIGRANTS: A COMPARATIVE STUDY OF THE VIETNAMESE MIGRANT COMMUNITY IN THE CZECH REPUBLIC AND THE NEW IMMIGRANTS IN TAIWAN

\section{Linguistic Integration of Adult Migrants (LIAM): Requirement of the Host Language}

According to the 2013 survey, out of the 36 Council of Europe member states, there were 26 states reporting that adult migrants are legally required to take a language courses and/or a language test for citizenship, 22 states for residence and 9 states prior to entry; a total of 29 reporting that to take a language requirement is legally necessary for at least one of the three mentioned administrative situations. Only 7 states have no such legislation (Council of Europe, 2014).

The core thinking of this language requirement is that language skills are an essential component of intercultural skills, of an absolute for everyday life in a multicultural world, and further to benefit fully from the cultural diversity, to be involved in intercultural dialogue, to be informed, and to understand. Language skills and knowledge of the host society are necessary for adult migrants to be involved and be responsible to the host society, and further to contribute themselves to social cohesion (Council of Europe, 2008b, pp. 8-9). However, the question of the language requirements of several states in relation to admission, residence or citizenship is becoming a major issue. Host language requirement seems to be the only and the most appropriate approach to achieve the goal of linguistic integration, although at the same time it possibly results in building up more distance from the ideal multilingualism, which will be discussed more in IV of this paper. ${ }^{26}$

As mentioned, there are generally two approaches to the requirement of host languages: language courses and/or language test. According to the Council of Europe Survey 2014, the number of states, which officially provide language courses, has increased from 2009 to 2013, whilst the courses are either compulsory or optional, free or fee-based. In 2013, 11 out of 17 states with a language requirement for residence officially provided language courses, but in 2009 only 9 states did so; while 10 out of 19 states with a language requirement

\footnotetext{
26 It is necessary to note here that more and more EU member states have already conducted impact studies of this language requirement for adult migrants. Until now, there are 14 states reported the importance of such studies. (Council of Europe, 2014).
} 
for citizenship officially provided languages courses in 2013, but only 6 states did so in 2009.

On the other hand, there is also a growing tendency of taking language and knowledge-of-society tests, in order to verify the degree of language proficiency. Language requirements are usually expressed in terms of the proficiency levels of the Council of Europe's Common European Framework of Reference for Languages (CEFR ${ }^{27}$ ). From the Table 1 below, it is obvious that the requirement with a specific CEFR level for residence and citizenship among EU member states is demanded over the years.

Table 1.

\section{Number of countries requiring different CEFR levels for residence and citizenship in 2007, 2009 and 2013 (Council of Europe, 2014, p. 18)}

\begin{tabular}{|c|c|c|c|c|c|c|}
\hline \multirow{2}{*}{$\begin{array}{c}\text { CEFR- } \\
\text { level }\end{array}$} & 2007 & & 2009 & & 2013 & \\
\cline { 2 - 7 } & Residence & Citizenship & Residence & Citizenship & Residence & Citizenship \\
\hline A1 & 2 & 1 & 2 & & 3 & \\
\hline A2 & 2 & 1 & 1 & 1 & 5 & 4 \\
\hline B1 & & 2 & 3 & 5 & 2 & 6 \\
\hline B2 & & 2 & & 1 & & \\
\hline A1/A2 & 2 & & 2 & & & \\
\hline A1/B1 & 2 & & 1 & & 2 & 1 \\
\hline A2/B1 & & & & 1 & & 2 \\
\hline A2/B2 & 1 & & 1 & & & \\
\hline
\end{tabular}

The level required for residence is mainly from $A 2$ to $B 1$, and for citizenship the required level is higher, mostly $B 1$. This requirement of language proficiency accompanies some problems to be solved, mainly lying in the related language courses, textbooks, teachers and so on. For example, currently there is a project named "Citizenship Language pack for migrants in Europe - L-PACK", which has been funded, with the support from the Europe Commission, in order to collect and prepare specific materials for teaching and learning the host language of nonEU migrants. So far, there are 8 languages involved in this project and starting

27 CEFR: Common European Framework of Reference for Languages: Learning, Teaching, Assessment. 2001. Council of Europe/Cambridge University Press. Available on line: www.coe.int/lang 
LIMITS OF THE EU LANGUAGE EDUCATION POLICY FOR MIGRANTS: A COMPARATIVE STUDY OF THE VIETNAMESE MIGRANT COMMUNITY IN THE CZECH REPUBLIC AND THE NEW IMMIGRANTS IN TAIWAN

from January 2014, an online L-PACK2 course $^{28}$, under the name of this project, was developed: A2 level course of colloquial Italian, Spanish, German, Lithuanian, Greek and Czech as second language addressed to adult migrants. The tendency of emphasizing the importance of linguistic integration for adult migrants is undoubtedly increasing. The EU member states will expectedly put more efforts on this issue in order to integrate the newcomers into their continent. However, from another point of view, it is also necessary to consider the typical features of migration: the origin of migration, the nature of migration and so on. For example, if most migrants are uneducated or unfamiliar with the knowledge of internet, how could they efficiently utilize the resources, such as L-PACK2, for their learning of the host language?

\section{Mother tongue of migrants}

Moreover, it is necessary to take the need of mother tongue of migrants into account, especially for children from a migrant background. On the other hand, not only for children of migrants, but also for the whole host society, it is also crucial to perceive the importance of knowledge and culture of migrants' mother tongues. For the EU, language continues to be regarded as an important component of integration, but a two-way approach of linguistic integration would be the best for the future development. According to the empirical study from the settled or resident immigrants and those who have become citizens, their mother tongues of origin "may change functional and symbolic status in individual repertoires - these languages may see their fields of use narrow or become specialized, and they may even cease to be used in the family" (Council of Europe, 2008a) These changes might not have the direct relation with the status of these languages. However, for the time being, especially for the children and the second generation of migrants, some of their mother tongues might be kept or only functioned as languages of identity; some of them might be lost and socalled linguistic integration might become a slogan only: while, in fact, this kind of "integration" would only turn into "assimilation", instead of "multilingualism". As a result, it is necessary to put mother tongues of migrants as an important

\footnotetext{
${ }^{28}$ See: http://www.l-pack.eu/.
} 
Melissa SHIH-HUI LIN

variation into a successful linguistic integration. In other words, it is essential to understand migrants in depth for the sake of host society. In the following, this paper will present a case of empirical study in Vietnamese migrant community in the Czech Republic.

\section{The Vietnamese migrant community in the Czech Republic}

This part focuses on one non-European migrant's community in a Central and Eastern European country, i.e. the Vietnamese migrant community in the Czech Republic. First, the unique historical background of this Asian community in the Czech Republic will be introduced; secondly, it proceeds with some main issues in the linguistic integration policy conducted in this territory after 2004, when the Czech Republic received the membership of European Union. Lastly, some impact brought by the linguistic integration policy to the Vietnamese migrant community will be discussed.

\section{General information}

According to the data of the Czech Statistical Office in March 2014, the immigrants to this territory are mainly Slovakian, Ukrainian and Vietnamese, i.e. Table 2.

Table 2.

Population of foreigners in the Czech Republic in 2001 and 2011 (Czech Statistical Office, 2014) $)^{29}$

\begin{tabular}{|c|c|c|c|c|c|c|c|c|}
\hline \multirow{3}{*}{ Nationality } & \multicolumn{4}{|c|}{2001} & \multicolumn{4}{|c|}{2011} \\
\hline & \multirow{2}{*}{ number } & \multirow{2}{*}{$\%$} & \multicolumn{2}{|c|}{ rate $\%$} & \multirow{2}{*}{ number } & \multirow{2}{*}{$\%$} & \multicolumn{2}{|c|}{ rate $\%$} \\
\hline & & & male & female & & & male & female \\
\hline $\begin{array}{c}\text { Foreigners in } \\
\text { total } \\
\text { therefrom }\end{array}$ & 124668 & $\begin{array}{c}100, \\
0\end{array}$ & 53,4 & 46,6 & 422,276 & 100,0 & 57,4 & 42,6 \\
\hline Slovakia & 24201 & 19,4 & 54,1 & 45,9 & 82251 & 19,5 & 53,7 & 46,3 \\
\hline
\end{tabular}

${ }^{29}$ See: https://www.czso.cz/csu/czso/cizinci-v-ceske-republice-podle-dat-scitani-lidu-2011dxfg9l7fpy. 
LIMITS OF THE EU LANGUAGE EDUCATION POLICY FOR MIGRANTS: A COMPARATIVE STUDY OF THE VIETNAMESE MIGRANT COMMUNITY IN THE CZECH REPUBLIC AND THE NEW IMMIGRANTS IN TAIWAN

\begin{tabular}{|c|c|c|c|c|c|c|c|c|}
\hline \multirow{3}{*}{ Nationality } & \multicolumn{4}{|c|}{2001} & \multicolumn{4}{|c|}{2011} \\
\hline & \multirow{2}{*}{ number } & \multirow{2}{*}{$\%$} & \multicolumn{2}{|c|}{ rate $\%$} & \multirow{2}{*}{ number } & \multirow{2}{*}{$\%$} & \multicolumn{2}{|c|}{ rate $\%$} \\
\hline & & & male & female & & & male & female \\
\hline Ukraine & 20628 & 16,6 & 47,2 & 52,9 & 116139 & 27,5 & 57,3 & 42,7 \\
\hline Vietnam & 18210 & 14,6 & 61,4 & 38,6 & 52612 & 12,5 & 58,9 & 41,1 \\
\hline Russia & 7696 & 6,2 & 44,1 & 55,9 & 31545 & 7,5 & 45,2 & 54,8 \\
\hline Poland & 13350 & 10,7 & 36,1 & 63,9 & 16800 & 4,0 & 47,6 & 52,4 \\
\hline
\end{tabular}

From the Table 2 above, it is of an interesting observation that out of all non-EU states, Vietnamese is the third major migrant community in the Czech Republic, and its population has increased from 18,210 in 2001 to 52,612 in 2011.

"The first groups of Vietnamese arrived in the Czech Republic as a consequence of the 1955 agreement on economic, scientific and technical cooperation between Czech Republic and the Vietnamese Democratic Republic" (Neustupný \& Nekvapil, 2003, p. 213), the renowned international aid among socialist/communist countries in the 1950s (Drbohlav \& Dzúrová, 2007) The number of Vietnamese moved to Czech Republic had increased gradually and until the beginning of the 1980s, there were approximately 30,000 resided in the territory of Czech Republic (Neustupný \& Nekvapil, 2003). The Vietnamese who arrived in Czech Republic in 1970s and 1980s were mostly guest-workers, mainly to fill some gaps in the Czech Republicn labor market. In 1981, two thirds of the Vietnamese in this territory were workers (Drbohlav et al., 2004). According to Drbohlav and Dzúrová (2007), judging the time of arrival of each Vietnamese group in Czech Republic, there were "mediators" who had come years ago to greatly monitor, politically, the stay of each newcomer. The "mediators" normally spoke Czech and was familiar with the administration and legislation. They functioned seemly as the interface between Vietnamese and Czech, though illegally. On the other hand, the existence of "mediators" brought less motivation for Vietnamese to learn more of the Czech language and culture. The Vietnamese community at that time was quite isolated in the territory. In 1986, the number of Vietnamese migrants started decreasing when economic reforms 'Doi Moi' started 
Melissa SHIH-HUI LIN

in Vietnam, but increased again after the Velvet Revolution in 1989 (Drbohlav \& Dzúrová, 2007).

\section{Linguistic Integration in the Czech Republic after 2004}

The Czech Republic has been a member of the EU since 2004. Growing flows of international migration complicate the language and cultural situation in this territory. Following the new amendment to the linguistic integration in Council of Europe, some changes have been conducted in the Czech Republic. According to Council of Europe (2008b), the migrants have the right to residence after an uninterrupted stay of five years in the Czech Republic, and the right to citizenship after ten years. Under the amended law, migrants have to present a certificate of knowledge of the Czech language from January, 2009. In 2009, the Czech Republic required level A1 of the Czech language for residence, and in 2015 changed to introduce a level A1 test for long-term stay and level A2 for permanent residence. For citizenship, the Czech Republic replaced the interview in 2008 by level B1 from 2014. The government also provides optional Czech courses free of charge that make it possible for migrants to attain the level required by law, but surely the courses are conducted for limited hours. According to Council of Europe (2014), this measure is quite unique among the eastern European countries, while most of them seldom provide such courses.

Another important amended law concerning the linguistic integration for children from a migrant background is free Czech language courses for all foreigner pupils in primary schools. According to the research result carried out by Kostelecká and Jančařík (2014), in 2009, 2010 and 2011, one of the most important factors significantly affecting the successful integration of children with foreign mother tongue into the Czech primary school system is the ability to communicate in Czech. In 2012, Czech legislation was amended to ensure free preparation for entering the primary school system, including Czech language classes tailored to the needs of learners, is now extended to all foreigners (Kostelecká \& Jančař́k, 2014). All in all, according to the new amended laws based on the idea of linguistic integration, it is apparent that the Czech Republic follows and adapts to the trend of learning the host language for migrants as one of the most important steps for integration. 
LIMITS OF THE EU LANGUAGE EDUCATION POLICY FOR MIGRANTS: A COMPARATIVE STUDY OF THE VIETNAMESE MIGRANT COMMUNITY IN THE CZECH REPUBLIC AND THE NEW IMMIGRANTS IN TAIWAN

\section{Some effects on the Vietnamese in the Czech Republic and the host society}

According to the data shown by the Czech Statistical Office, in 2014 June, i.e. Table 3, the percentage of population which declares to hold single ethnicity was decreasing: $98.2 \%$ in 2001 to $73.1 \%$ in 2011. Among them, the number of population declares themselves as Vietnamese was increasing: 17,462 in 2001 to 29,660 in 2011.

Table 3.

Ethnicities in the Czech Republic in 2001 and 2011

(Czech Statistical Office, 2014) ${ }^{30}$

\begin{tabular}{|l|c|c|c|c|}
\hline \multirow{2}{*}{\multicolumn{1}{|c|}{ Residents in total: }} & \multicolumn{2}{c|}{2001} & \multicolumn{2}{c|}{2011} \\
\cline { 2 - 5 } & total & $\%$ & total & $\%$ \\
\hline $\begin{array}{l}\text { who claims to hold single } \\
\text { ethnicity }\end{array}$ & 10230060 & 100,0 & 10436560 & 100,0 \\
\hline Czech & $\mathbf{1 0 0 4 4 2 5 5}$ & $\mathbf{9 8 , 2}$ & $\mathbf{7 6 3 0 2 4 6}$ & $\mathbf{7 3 , \mathbf { 1 }}$ \\
\hline Moravian & 9249777 & 90,4 & 6711624 & 64,3 \\
\hline Silesia & 380474 & 3,7 & 521801 & 5,0 \\
\hline Slovakia & 10878 & 0,1 & 12214 & 0,1 \\
\hline Polish & 193190 & 1,9 & 147152 & 1,4 \\
\hline German & 51968 & 0,5 & 39096 & 0,4 \\
\hline Romany & 39106 & 0,4 & 18658 & 0,2 \\
\hline Hungarian & 11746 & 0,1 & 5135 & 0,0 \\
\hline Vietnamese & 14672 & 0,1 & 8920 & 0,1 \\
\hline Ukrainian & 17462 & 0,2 & 29660 & 0,3 \\
\hline Russian & 22112 & 0,2 & 53253 & 0,5 \\
\hline Other & 12369 & 0,1 & 17872 & 0,2 \\
\hline $\begin{array}{l}\text { who claims to hold double } \\
\text { ethnicities }\end{array}$ & 40501 & 0,4 & 58289 & 0,6 \\
\hline Czech and Moravian & $\mathbf{1 2 9 7 8}$ & $\mathbf{0 , 1}$ & $\mathbf{1 6 3 6 4 8}$ & $\mathbf{1 , 6}$ \\
\hline Czech and Slovakia &. &. & 99028 & 0,9 \\
\hline Czech and Romany & $\mathbf{1 7 2 8 2 7}$ & $\mathbf{1 , 7}$ & $\mathbf{2 6 4 2 6 6 6}$ & $\mathbf{2 5 , 3}$ \\
\hline Czech and German & 6983 & 0,0 & 17666 & 0,2 \\
\hline Other combinations & & 0,0 & 7026 & 0,1 \\
\hline others & & $\cdot$ & 6158 & 0,1 \\
\hline
\end{tabular}

${ }^{30}$ See: https://www.czso.cz/csu/czso/narodnostni-struktura-obyvatel-2011-aqkd3cosup. 
There might be many other reasons to support the change mentioned above. However, it is interesting that the ethnic identity of the Vietnamese community in the Czech Republic has increased, despite of the fact that the related authority put more effort into the work of integration. Certainly, there is no direct relation between the effects of integration and the ethnic identity, but the isolation of the Vietnamese community in the Czech Republic is well-known. According to Drbohlav \& Dzúrová (2007):

Their isolation is supported by their very intensive 'internal', not 'external', social communication and perhaps also by their perceived cultural distance from the Czech majority population...They did choose a path that combines rapid economic advancement with deliberate preservation of the immigrant community's values and solidarity (p. 88).

This statement might precisely explain the phenomenon, which can occur in almost all the small Vietnamese shops in this territory: the shop owners are always watching Vietnamese TV programs or listening Vietnamese music when you enter the shop, or a small Buda is placed somewhere at the corner. The Vietnamese community until now still maintains their own cultural value, living style and even much internal solidity in the Czech Republic, although the community has existed in this society for more than half century.

Another important factor that seems instrumental in immigrant inclusion into Czech society, particularly via cultural activities, is the existence of ethnic institutions. There are around ten registered Vietnamese associations working in this country; however, only four are well-known (Drbohlav and Dzúrová, 2007). One of them is the Association of Vietnamese Entrepreneurs (in Czech: Svaz vietnamských podnikatelů), established in 1992; in the same year, Vietnamese Association (in Czech: Svaz Vietnamců) was formed in Prague to protect the interests of the community. They have a branch in Ostrava. A new magazine, Bambus, was founded in 2003 (Neustupný \& Nekvapil, 2003)

Regardless of proper understanding in depth of the nature, culture and religion of migrants, the authority goes by the main principle of linguistic integration: good knowledge of the Czech language seemly serves as the only gateway to integration. Additionally, it appears that successful inclusion in Czech society is connected to the assimilation mode, which might bring some opposite effects, not only to the Vietnamese community, but also to the host society. It is 
essential to note that the second generation of the Vietnaemese community in this territory has developed in contrast. Most of them were born in the Czech Republic and had Czech education. They have very good knowledge of Czech, as Czech locals. Some of them even hold Czech identity and it has become a phenomenon. It still remains unknown if any impact had been brought by the contrasting development between Vietnamese migrants and their second generation. For the host society, according to Neustupný \& Nekvapil (2003), the attitude the public holds towards the Vietnamese community is disparate. Pejorative descriptors such as "cane people" and "reed warblers" are sometimes used to refer to the Vietnamese people in the Czech society. There was a survey conducted by the public opinion research center of Institute of Sociology at Academy of Sciences of the Czech Republic (CVVM) in March 2016 on the relationship to the ethnic communities living in the Czech Republic, as presented in Table 4 below:

Table 4.

\section{Relationship to the ethnic communities living in the Czech Republic $(\text { CVVM, 2016) })^{31}$}

\begin{tabular}{|l|c|c|c|c|c|c|}
\hline & $\begin{array}{c}\text { very } \\
\text { pleasant }\end{array}$ & $\begin{array}{c}\text { rather } \\
\text { pleasant }\end{array}$ & $\begin{array}{c}\text { neither } \\
\text { pleasant nor } \\
\text { unpleasant }\end{array}$ & $\begin{array}{c}\text { rather } \\
\text { unpleasant }\end{array}$ & $\begin{array}{c}\text { very } \\
\text { unpleasant }\end{array}$ & \\
\hline & 1 & 2 & 3 & 4 & 5 & average \\
\hline Czechs & 50 & 35 & 13 & 1 & 0 & 1,66 \\
\hline Slovakians & 35 & 46 & 17 & 2 & 0 & 1,88 \\
\hline Polishes & 10 & 34 & 38 & 12 & 3 & 2,61 \\
\hline Germans & 6 & 28 & 39 & 19 & 5 & 2,87 \\
\hline Greeks & 6 & 24 & 39 & 14 & 6 & 2,88 \\
\hline Jews & 5 & 22 & 42 & 12 & 6 & 2,91 \\
\hline Hungarians & 5 & 21 & 44 & 15 & 5 & 2,93 \\
\hline Vietnamese & 6 & 26 & 42 & 17 & 8 & 2,96 \\
\hline Bulgarians & 5 & 21 & 41 & 17 & 6 & 2,98 \\
\hline Russians & 4 & 18 & 41 & 25 & 9 & 3,18 \\
\hline Serbs & 2 & 14 & 42 & 18 & 9 & 3,21 \\
\hline Ukrainians & 3 & 17 & 42 & 25 & 11 & 3,26 \\
\hline Chinese & 3 & 14 & 39 & 23 & 11 & 3,27 \\
\hline
\end{tabular}

31 See:

http://cvvm.soc.cas.cz/media/com_form2content/documents/c1/a7547/f3/ov160420.pdf. 
Melissa SHIH-HUI LIN

\begin{tabular}{|l|c|c|c|c|c|c|}
\hline & $\begin{array}{c}\text { very } \\
\text { pleasant }\end{array}$ & $\begin{array}{c}\text { rather } \\
\text { pleasant }\end{array}$ & $\begin{array}{c}\text { neither } \\
\text { pleasant nor } \\
\text { unpleasant }\end{array}$ & $\begin{array}{c}\text { rather } \\
\text { unpleasant }\end{array}$ & $\begin{array}{c}\text { very } \\
\text { unpleasant }\end{array}$ & \\
\hline Romanians & 1 & 7 & 35 & 33 & 15 & 3,59 \\
\hline Albanians & 1 & 4 & 26 & 32 & 25 & 3,86 \\
\hline Arabs & 1 & 3 & 15 & 31 & 44 & 4,20 \\
\hline Gypsies & 1 & 2 & 14 & 34 & 48 & 4,26 \\
\hline
\end{tabular}

In Table 4, number 1 means "very pleasant"; number 2 means "rather pleasant"; number 3 means "neither pleasant nor unpleasant"; number 4 means "rather unpleasant"; number 5 means "very unpleasant". This figure is presented in percentage of the rolls. The relationship to the Vietnamese community falls on 2.96 in average, and most falls on the evaluation of "neither pleasant nor unpleasant". However, in fact, this number is already more positive than that of in previous years. Please see Table 5 :

Table 5.

Relationship to the ethnic communities living in the Czech Republic from 2013 to $2016(\text { CVVM, 2016) })^{32}$

\begin{tabular}{|l|c|c|c|c|}
\hline & III/2013 & III/2014 & II/2015 & III/2016 \\
\hline Czechs & 1,69 & 1,58 & 1,59 & 1,66 \\
\hline Slovakians & 1,79 & 1,72 & 1,76 & 1,88 \\
\hline Polishes & 2,47 & 2,40 & 2,47 & 2,61 \\
\hline Germans & 2,87 & 2,83 & 2,82 & 2,87 \\
\hline Greeks & 2,72 & 2,58 & 2,72 & 2,88 \\
\hline Jews & 2,80 & 2,67 & 2,83 & 2,91 \\
\hline Hungarians & 2,96 & 2,80 & 2,88 & 2,93 \\
\hline Vietnamese & 3,26 & 3,09 & 3,11 & 2,96 \\
\hline Bulgarians & 2,98 & 2,88 & 2,95 & 2,98 \\
\hline Russians & 3,11 & 3,27 & 3,31 & 3,18 \\
\hline Serbs & 3,16 & 3,07 & 3,19 & 3,21 \\
\hline Ukrainians & 3,57 & 3,36 & 3,44 & 3,26 \\
\hline Chinese & 3,35 & 3,28 & 3,25 & 3,27 \\
\hline Romanians & 3,60 & 3,56 & 3,55 & 3,59 \\
\hline Albanians & 3,66 & 3,65 & 3,74 & 3,86 \\
\hline Arabs & - & 3,79 & 4,02 & 4,20 \\
\hline Gypsies & 4,24 & 4,21 & 4,30 & 4,26 \\
\hline
\end{tabular}

32 See: the same as in the note of 13 . 
LIMITS OF THE EU LANGUAGE EDUCATION POLICY FOR MIGRANTS: A COMPARATIVE STUDY OF THE VIETNAMESE MIGRANT COMMUNITY IN THE CZECH REPUBLIC AND THE NEW IMMIGRANTS IN TAIWAN

In Table 5, the evaluation of the relationship to the Vietnamese community is numbered from 3.26 in 2013 to 2.96 in 2016, which decreased by 0.15 , building up toward a more positive attitude. This phenomenon also corresponds to some new commentaries on the Vietnamese community in the Czech society. For example in the speech of Current Czech President Miloš Zeman in Bratislava Slovakia on Feburary 12th in $2016^{33}$, he described the Vietnamese people are more "industrious" and have "no barrier" of communication, compared with the current refugee migrants. He also emphasized that the migration of the current refugees is the synonyms of "Islamic migration" and which is "not possible to integrate and is not capable of being assimilated into European culture." He might not represent of the entire Czech nation; however, his opinion reflected one popular myth that current refugee flows into Europe are all Islamists. It also explains the importance to understand the objects properly to integrate; there won't be any successful integration if correct knowledge about the migrants is non-existent. In Figure 7, the relationship to the Arabic community appears to be more negative over the years, from 3.79 in 2014 to 4.20 in 2016, which means almost "very unpleasant".

\section{Limits of the current linguistic integration in EU for migrants}

\section{Refugees as different migrants}

The current major migrants to Europe are so-called refugees, mainly fled from Middle-east, Ukraine and Northern Africa. It is necessary to take these "refugees" as different migrants. According to the Convention Relating to the Status of Refugees (1951):

$[A]$ ny person who: owing to a well-founded fear of being persecuted for reasons of race, religion, nationality, membership of a particular social group, or political opinion, is outside the country of his nationality, and is unable to or, owing to such fear, is unwilling to avail himself of the protection of that country (Article 1.A.2).

${ }^{33}$ See: https://www.youtube.com/watch?v=k6Pw4PHxEKM\&nohtmI5=False. 
Regarding the definition in the Convention Related to the Status of Refugees, "well-founded fear of being persecuted" and "is outside the country of his nationality" are two conditions served as the main factors to be identified as a refugee.

Due to the forced nature of their migration and their experiences, compared with other migrant groups, refugees will often have specific needs that have to be met in order to support their integration. It is therefore important that the special needs of refugees are recognized in integration policies and practice....within overall policy of mainstreaming (ECRE, 2005, p. 2).

In other words, refugees should be given sufficient educational and language provision to be able to speak the language of the asylum country, as well the appropriate access to educational institutions and to the labor market, so that they can participate actively in society. Societies, governments, mass mediums and educational organizations of host communities must recognize refugee protection as a moral and legal obligation of all European countries. It is widely acknowledged that the successful integration of refugees in European countries is of benefit to all, including refugees themselves, host communities, governments and so on.

\section{Acknowledgement of the nature of migrants}

As mentioned, there won't be any successful integration if host society has zero correct knowledge about the migrants, mainly of their language and culture. A two-way approach of linguistic integration would be served the best for mutual understanding the migrants and the host society.

Nowadays, immigrant communities isolated in European context are still of existence. The main reason behind such existence might be driven either by the huge cultural or religious differences between immigrant communities and host societies, or by the twisted European multilingualism. Once the authorities start being involved more in order to educate host societies on the knowledge about the language and culture of migrants, such gap or misunderstanding between the host society and the migrants should gradually be dismissed. The real cultural and linguistic diversity will be realized then, instead of being a slogan only. 
On the other hand, to understand the motivation of migration is also important; for example, it is necessary to distinguish the differences between economic and political migrants. Political migrants might be seen as refugees, seeking asylum, while migrants are to be seen as economic ones or an asset that contributes to economic growth, they will complement the domestic labor market. Migration is seen in terms of a management or assessment of migration need (Drbohlav \& Dzúrová, 2007)

\section{Teaching languages and language in teaching}

For children from a migrant background, the curriculum at schools and language used for teaching are key factors for their study and further development for integration of next generations of migrants. The language dimension in teaching and learning subjects should be taken into account in particular context and in how far it affects curriculum development, textbooks and teacher education. The authorities must consider that the problem of language used for teaching might arise the inequality from the beginning of study for children from a migrant background. According to Council of Europe (2015), with growing awareness of the importance of taking a broad approach to language education, "work in the field of foreign/second languages as well as in the field of the language(s) of schooling is seen in a perspective of plural lingual and intercultural education." There may be a challenge in how language aspects should be embedded in curriculum; however, for better integration, it is necessary to consider such sustainable development for the next generation of migrants.

\section{Some ideas cultivated from the language education policy of new immigrants in Taiwan}

In this part, some ideas cultivated from the language policy of so-called 'new immigrants' in Taiwan will be mentioned, and discussed for reference to linguistic integration in European context. 
According to 2010 Population and Housing Census of National Statistics in Taiwan $^{34}$, until the end of 2010 there are 562,233 foreigners in Taiwan; which occupies $2.5 \%$ population in Taiwan. Among them, 433,760 are from the Southeastern Asian countries: mainly from Thailand, Philippines, Indonesia and Vietnamese. The population contributed to such a high ratio of the Southeastern Asian migrants in Taiwan conducted their act of migration starting from the $1980 \mathrm{~s}$ by the trend. This trend grew rapidly along with the 1994 "Go-South Policy" of Taiwan's government (Chen, 2010). Most of these migrants from Southeast Asia to Taiwan currently are either migrant workers or marriage migrants. According to the Ministry of the Interior (MOI, 2009a), there are 414,699 marriage migrants in Taiwan, while the number of indigenous Taiwanese wives is of 494,107 . Out of these marriage migrants, 33.71\% are from Southeast Asia and 66.29\% from the PRC (MOI, 2009b). In addition, the number of "new Taiwan children", at least one of whose parents is a migrant, exceeded the number of native Taiwan children by 5,339 in 2009. Because of this relatively large number, linguistic and educational issues for these new migrants and their children have become a major concern in Taiwan (Chen, 2010).

In addition to promoting the host language and culture to migrants, Taiwan's government also put a focus on the mother tongue of migrants, which should be seen as cultural assets, assisting the country to enhance the competitiveness in the future. From this insight, the government has started organizing language related courses of migrants' mother tongues, to not only strengthen the language identity of migrants and their children, but also cultivate the appropriate attitude towards different languages for the whole society. For example, the Ministry of Education in Taiwan has started designing a new curriculum of primary and secondary schools, in which the mother tongues of new immigrants will be served as the options for language courses, which is expected to be launched from the academic year of 2018. Later on, each student from primary school is obliged to take either local or migrant language course; for the students from secondary school, these language courses will be optional. For growing demand, the mother tongues of new Taiwan immigrants designed as part of the new curriculum will be Vietnamese, Indonesian, Thai, Burmese and Cambodian. However, there are many unsolved problems accompanied this new

${ }^{34}$ See: http://ebas1.ebas.gov.tw/phc2010/chinese/rchome.htm. 
LIMITS OF THE EU LANGUAGE EDUCATION POLICY FOR MIGRANTS: A COMPARATIVE STUDY OF THE VIETNAMESE MIGRANT COMMUNITY IN THE CZECH REPUBLIC AND THE NEW IMMIGRANTS IN TAIWAN

curriculum: the number of schools with such demand, the resource and training of teachers, the preparation of language textbooks, and the most urgently, the acceptability of the whole society (Huang, 2015). Due to the emerged problems above, the Ministry of Education in Taiwan designed a two-year pilot project named "Parent and Children Learn Together" from March 2015, mainly to promote co-learning for new immigrants and their children within friendly learning environment, to help them understand local culture, and to as well raise the public awareness of the contribution from these new immigrants. So far, one elementary school in New Taipei City, one in Kaohsiung City, one in Hsinchu County, and another in Hualian County have participated in this pilot project. ${ }^{35}$ The result of this pilot project is still unknown, while the beginning of it has already arisen public awareness, which might be considered a success.

From the empirical study of Taiwan new immigrants above, recognizing the importance of two-way linguistic integration and necessity of language training of migrants' mother tongues is becoming a trend for a multilingual society in reality with cultural diversity. This might bring some thinking to the current migrant crisis in Europe, which would be discussed more in the conclusion.

\section{Conclusion: Integration or assimilation?}

A successful integration requires consideration on the interaction of languages and culture between migrants themselves and host community. If it is only conducted one-sided, integration has great chance of failing, and end up becoming assimilation. There is a need for the development of sustainable multilingualism in societies; which emphasizes the importance of each mother tongue, with a focus on the mother tongues of migrants. It is assumed that the only approach to have a successful integration in societies is to maintain the linguistic and cultural diversity. For example, as mentioned in the Taiwanese case, the government has started organizing language related courses of migrants' mother tongues. This policy does not only help building identities of migrants' second generation, but also strengthens the mutual dialogue between

35 See: http://www.k12ea.gov.tw/ap/en_tpdenews_view.aspx?sn=4dafdcc3-4804-481aa322-d5a34e524801. 
schools and such families with migration background. The goal of this policy is to minimize assimilation and allow the immigrants to preserve their own heritage languages and culture.

Most of the language policies for migrants are passively oriented, i.e. forced by the circumstance/flows of migrants. However, the authority must think thoroughly of this issue in active, in order to prevent the problems caused by the lack of consideration. The current EU language policy for migrants emphasizes more on the acquisition the languages of host societies; although the promotion of intercultural dialogue has been also stressed as a political priority for the organization, the European society generally is lack of such recognition. For example, the second generation of the Vietnamese community in the Czech Republic, mostly young and well-educated Vietnamese in this territory, are to be assimilated and have developed disparately, compared with their native families isolated from the host society. To resist assimilation, direct and indirect ties with the origin country and the associated cultures and languages are to be remained, when conducting integration in the host society.

The main motivation for Taiwan's government to take the reform of the language education policy for Taiwan new immigrants is the rapidly increasing number of immigrant population, when the second generation of migrants has become the main composition of population. Currently, Europe faces the numerous flows of refugee migrants, not to mention the informal and/or formal encampments for transiting migrants, which will undoubtedly expect the emerging problems raised by their second generation. The relevant reform must be taken into consideration for EU.

As discussed in IV of this paper, in order to achieve a better linguistic integration, it is necessary for the EU to take the following points into consideration: first, to take refugees as different migrants, which means recognizing refugee protection as a moral and legal obligation for all European countries; secondly, to acknowledge the nature of migrants, which emphasizes the education about the nature of migrants to host societies, mainly to achieve the mutual integration between host societies and migrants; and finally, to develop curriculums for next generations of migrants not only about languages of host societies but also about mother tongues of migrants, to pursue a more sustainable development. Nevertheless, it is necessary to recall the original value 
LIMITS OF THE EU LANGUAGE EDUCATION POLICY FOR MIGRANTS: A COMPARATIVE STUDY OF THE VIETNAMESE MIGRANT COMMUNITY IN THE CZECH REPUBLIC AND THE NEW IMMIGRANTS IN TAIWAN

of European Union, i.e. the linguistic and cultural diversity, and the maintenance of multilingual and multicultural development, which should be served as the first step to face the unsolved issues with the migrations nowadays. Such approach should not only be applicable to Europe's current status, but also to the various present conditions worldwide.

\section{References}

Aiyar, S., Bergljot, B., Batini, N., Berger, H., Detragiache, E., Dizioli, A., Ebeke, C., et al. (2016). The refugee surge in Europe: Economic challenges. Washington, D.C.: International Monetary Fund.

Chen, M. (2010). Becoming Taiwanese: Self-perception of the new Taiwanese immigrant female. International Journal of Asia Pacific Studies, 6(2), 122.

Council of Europe. (2008a). The role of languages in policies for the integration of adult migrants. Concept Paper prepared for the Seminar: The Linguistic integration of adult migrants. Strasbourg: Language Policy Unit and Migration Unit.

Council of Europe. (2008b). The Linguistic integration of adult migrants. Report on Intergovernmental Seminar. Strasbourg: Language Policy Unit.

Council of Europe. (2014). Linguisitc integration of adult migrants: Final report on the $3^{\text {rd }}$ Council of Europe survey. Strasbourg: Language Policy Unit.

Council of Europe. (2015). Seminar report on the language dimension in all subjects. Strasbourg: Language Policy Unit.

Drbohlav D., et al. (2004). Vyzkumma zprava: Integrace cizincu v CR. Studie armenske, vietnamske a ukrajinske komunity v Praze a Stredoceskem kraji. Prague: International Organization for migration.

Drbohlav D., \& Dzúrová, D. (2007). "Where are they going?": Immigrant inclusion in the Czech Republic (a case study on Ukrainians, Vietnamese, and Armenians in Prague). International Migration, 45(2), 69-95.

European Commission. (2007). Eurobarometer special 273, European social reality. Brussels: European Commission. 
European Council on Refugees and Exiles (ECRE). (2005). The way forward: Towards the integration of refugees in Europe. Brussels: European Council on Refugees and Exiles.

Grin, F. (1995). Combining immigrant and autochthonous language rights: A territorial approach to multilingualism. In T. Skutnabb-Kangas \& R. Phillipson (Eds.). Linguistic Human Rights: Overcoming linguistic discrimination (pp. 31-48). Berlin: Mouton de Gruyter.

Guy, G. (1989). International perspectives on linguistic diversity and language rights. Language Problems and Language Planning, 13, 45-53.

Hoffmann, C. (1991). An introduction to bilingualism. London: Longman.

Huang, J. J. (2015). Limits and breakthrough of curriculum policy: Surrounding education for new immigrants in Taiwan. Journal of Curriculum Studies, $10(2), 1-15$.

Jackson, D., \& Pasarelli, A. (2008). Mapping migration: Churches' responses. Brussels: Churches Commission for Migrants in Europe.

Kostelecká Y., \& Jančařík, A. (2014). The process of Czech language acquisition by foreign pupils at lower secondary school. ERIES Journal, 7(1), 7-13.

Marshall, D. F. (Ed.) (1986). The question of an official language: language rights and the English Language Amendment. International Journal of the Sociology of Language, 60, 7-75.

Marta, C. (1991). From assimilation to multiculturalism: Twenty years of policy and social research on immigration in Sweden (1966-1985). Studi Emigrazione/Etudes Migrations, 28(101), 59-81.

Ministry of Interior (MOI), Taiwan, ROC. (2009a). Population of the TNIFs of 2009

(In Chinese: Waijipeiou yu dalu gangaopeiou renshu). Retrieved from: http://www.ris.gov.tw/346\#.

Ministry of Interior (MOI), Taiwan, ROC. (2009b). Population of the native Taiwanese (In Chinese: Taiwan Yuanzhumin renshu). Retrieved from: http://www.ris.gov.tw/346\#.

Neustupný, J. V. \& Nekvapil, J. (2003). Language management in the Czech Republic. Current Issues in Language Planning, 4, 181-366.

Schneider, J., \& Crul, M. (Eds.) (2012). Theorising integration and assimilation. London and New York: Routledge. 
LIMITS OF THE EU LANGUAGE EDUCATION POLICY FOR MIGRANTS: A COMPARATIVE STUDY OF THE VIETNAMESE MIGRANT COMMUNITY IN THE CZECH REPUBLIC AND THE NEW IMMIGRANTS IN TAIWAN

Skutnabb-Kangas, T. \& Phillipson, R. (1989). Wanted! Linguisitc human rights. ROLIG-papir 44. Roskilde: Roskilde University Centre.

Steiner-Khamsi, G. (1989). Ausländische sprachliche minderheiten in der Schweiz (Immigrant Language Minorities in Switzerland). In eidgenössisches department des inner: Materialienband zum schlussbericht der arbeitsgruppe zur revision von artikel 116 der Bundesverfassung (pp. 89100). Bern: Bundeskanzlei.

\title{
Melissa Shih-hui Lin
}

Nacionalinis Chengchi universitetas, Taivanas; shihhui@nccu.edu.tw

\section{ES KALBU POLITIKOS APRIBOJIMAI MIGRANTAMS: VIETNAMIEČIU BENDRUOMENĖS ČEKIJOS RESPUBLIKOJE IR TAIVANIO NAUJUUU IMIGRANTU LYGINAMASIS TYRIMAS}

\begin{abstract}
Santrauka. Europos Tarybos kalbu politikos tikslas - skatinti daugiakalbystę, lingvistinę ivairovę, abipusi supratima, demokratini pilietiškuma ir socialinę sanglaudą. Migrantu bendruomenems svarbios naujausios lingvistinès integracijos igyvendinimo iniciatyvos: Lingvistinè suaugusiuju migrantu integracija (LIAM) ir Vaiku iš migrantu šeimu integracija kalbos ugdymo ir kitais švietimo klausimais. Tačiau dèl šiuolaikinès pabègèliu krizès Europoje padariniu, šiu strateginiu nuostatu igyvendinimas gana ribotas ir susiduria su netikètais sunkumais. Būtent šie esminiai klausimai ir nagrinejami straipsnyje. Vietnamiečiai atvyko i Čekijos Respubliką 1970-aisiais ir 1980-aisiais kaip svečiai-darbininkai. Kaip rodo Čekijos statistikos tarnybos (CZSO) atlikto gyventoju surašymo duomenys, $1985 \mathrm{~m}$. Cekijos teritorijoje gyveno 19350 vietnamiečiu, bet iki $1994 \mathrm{~m}$. ju skaičius ženkliai sumažèjo, iki apytikriai 8000 . Tačiau $2014 \mathrm{~m}$. gyventoju surašymo duomenys rodo, kad dèl pokyčiu politineje ir ekonomineje aplinkoje Cekijos Respublikos teritorijoje gyvenančiu vietnamiečiu skaičius laikotarpiu nuo 2001 iki 2011 stipriai išaugo, nuo 18210 iki 52 612. Spejjama, kad šie skaičiai gali būti dar didesni, nes tikrasis Čekijos Respublikos teritorijoje gyvenančiu vietnamiečiu skaičius nèra tikslus dèl nelegalios migracijos - daugelis imigrantu nèra registruoti ir neturi gyvenama vieta patvirtinančiu dokumentu. Pasak CZSO, $2014 \mathrm{~m}$. vietnamiečiu bendruomenè sudarè $12,5 \%$ Čekijos teritorijoje gyvenančiu migrantu populiacijos, ir tai yra trečioji didžiausioji migrantu bendruomenè po slovaku ir ukrainiečiu. Čekijos vyriausybe patvirtino kalbos politikos programas migrantu integracijai, kuriu igyvendinimas atnešè ir teigiamos, ir neigiamos naudos visai visuomenei. Šiame straipsnyje trumpai pristatysime ES lingvistinès integracijos iniciatyvas, empirinę vietnamiečiu kaip trečios didžiausios migrantu bendruomenès Čekijos Respublikoje situacijos analizę Europos kontekste ir pabaigoje aptarsime Taivanio šiuolaikinès naujuju imigrantu kalbos ugdymo politika, kuri yra atsparos taškas sprendžiant šiuolaikinès pabègèliu krizès keliamas problemas specifiniu lingvistinès integracijos Europoje atžvigiu.
\end{abstract}

Pagrindinès sąvokos: migracija, lingvistinè integracija, lingvistinès teisès, vietnamiečiai Čekijoje, Europos Sajunga, Taivanis ir naujieji imigrantai. 